\title{
Sustainability of Lesson Study on The Lesson Study for Learning Community (LSLC) Program in Batu City East Java Province
}

\author{
Moch. Agus Krisno Budiyanto ${ }^{1}$, Abdulkadir Rahardjanto ${ }^{2 *}$, Samsun Hadi ${ }^{3}$, H. \\ Husamah4
}

1,2,3,4 Department of Biology Education, Universitas Muhammadiyah Malang, East Java, Indonesia

\begin{tabular}{l} 
A R T I C L E I N F 0 \\
\hline Article history: \\
Received 18 December \\
2020 \\
Received in revised \\
Form 06 January 2021 \\
Accepted 01 February \\
2021 \\
Available online 03 \\
February 2021 \\
\hline
\end{tabular}

Keywords:

Batu City, Lesson Study, LSLC, Multidimensional Scaling. Sustainability

\begin{abstract}
A B S T R A C T
LSLC was an innovative learning program. Much research has been done regarding the implementation of LSLC, but few have focused on its sustainability. This study aimed to discover the sustainability of LSLC in Batu City. This study was a quasi-research using multivariate multidimensional scaling analysis. The population used was all the piloting LS schools and LSLC experts from universities. The results obtained present a good result on the development side of students' cognitive, affective, and psychomotor domains. Good development was revealed in the dimensions of pedagogic, competence, and commitment. In the subsidy and socio-cultural dimensions, shows unfavorable results and requires serious attention. It can be concluded that the sustainability of LSLC requires special attention to several dimensions. Therefore, various studies that can be focused on that dimension need to be done, so that the right model/solution can be found to ensure the sustainability.
\end{abstract}

\section{Introduction}

Development of Lesson Study (LS) is based on the didactic situation theory which has the hypothesis that teachers' professional knowledge is developed through action, interaction, formulation, validation, and didactic institutionalization in their learning environment (Wood, 2018). LS reveals a collaborative collaboration among the teachers and other education activists (Chenault, 2017; Gutierez, 2015; Merga, 2019), in which it focuses on the teacher professional learning and students' learning (Coenders \& Verhoef, 2019; Purwanti \& Hatmanto, 2019; Uştuk \& Çomoğlu, 2019). The scope of the LS more leads to ontology on the learning difficulties (Norwich \& Jones, 2012; Rappleye \& Komatsu, 2017).

LS more sharply due to the use of this program can: (1) see in detail and sharply if it is compared with the learning in general. (2) see the gap between the assumptions that the teacher imagines when the students learn and what actually happens when the students learn. (3) discover how to plan the lesson that is suitable with the students' needs and (4) alter the teaching patterns by giving more emphasis on how the students learn (Dudley, 2013).The activities carried out by the teachers on LS can develop theoretical coherence and build up a better pedagogical system (Bjuland \& Mosvold, 2015; Ngang \& Sam, 2015; Tan et al., 2019). The teachers can develop broadly the cognitive function of students so that it can underlie the architectural thinking and behavior patterns (Baymuradovna et al., 2020; Lofthouse \& Cowie, 2018; Widoretno \& Dwiastuti, 2019). This development requires supportive system that is complex on the field implementation (Alamri, 2020; Angeles \& Matsuura, 2020; Cresswell et al., 2013; Kaen et al., 2011; Kanellopoulou \& Darra, 2019).

Therefore, supportive study of LS is an interdependency of brain ware, hardware, funding, and networking of educational stakeholders (Hindun et al., 2019; Miharja et al., 2017; Nurwidodo, 2016a, 2016b; Nurwidodo et al., 2018). This system will be sustainable if the supportive program has a dynamic ability that is active in regulating itself. Handling that is not well integrated between the LS and the current Curriculum of 2013 can cause a conflict of interest (Rahardjanto \& Susilowati, 2018).

In a more specific context, several schools in Batu City, East Java Province have collaborated with related universities independently and took the initiative to implement the Lesson Study for Learning Community (LSLC) program. The ability of education managers to independently regulate LSLC will be 
able to determine the sustainability of the program being carried out, so this needs to be studied specifically and comprehensively as a basis for policy making and future (sustainable) reflection.

However, studies on the potential for the sustainability of LSLC - which can be both best practices and reflections - have not been widely carried out, and can even be categorized as rare. Several LSLC studies (in international publication context/reputable) are more focused on concepts (Lim-Ratnam et al., 2019; Saito \& Atencio, 2015; Sato, 2018; Tsukui \& Murase, 2018), activities, implementation of learning, and LSLC initiation in schools (Haerullah et al., 2019; Herliani \& Masitah, 2018; E. W. K. Lim, 2015; Merdekawati, 2020; Purwandi et al., 2020; Rozimela, 2018; Saito \& Atencio, 2015; Saito \& Sato, 2012; S. Suratno et al., 2020; T. Suratno et al., 2019; Yuniar et al., 2020), process of assessing and the implementation LSLC (Setyawan et al., 2019), and ideas about the importance of networking (Nurwidodo et al., 2018). Especially in Batu City, there is only one study that has focused on the implementation of LSLC since 2016 (Hindun et al., 2019). Of course, this will be a problem for efforts to maximize the impact of LSLC because implementation problems in the field are not mapped.

In this connection, this study aims to determine the index of sustainability of the LSLC program in Batu City, East Java Province. The contribution of the results of this study is to provide an overview of the potential sustainability of the LSLC program in Batu City which is based on innovative and independent activities of schools involved in teaching in schools. The results of this research will serve as signposts for LSLC activists, the government or policy makers, LSLC experts, and schools in implementing appropriate and sustainable LSLC (which has the maximum impact on improving the quality of education and learning in schools).

\section{Methods}

This study has respondents of all piloting LS schools in Batu City and the experts of LS who are active in LSLC activities in Batu city. The instruments of study used to grab the data are by using questionnaires and observation sheets of program sustainability developed based on the sustainability model of RAPRICons, of which model is developed by (Rahardjanto, 2015) using modification of dimensions, namely: (1) Pedagogic Dimensions, (2) Competence Dimensions, (3) Socio-Cultural Dimensions, (4) Commitment Dimensions, and (5) Subsidy Dimensions. The five dimensions developed are characteristics of the sustainability of the education sector. The dimensional attributes obtained are converted into a binary scale and then processed by multivariate analysis of interdependent multidimensional scaling (MDS) which is then followed by a rotation process. Root Mean Square (RMS) on the $\mathrm{X}$ ordination axis will determine the level of sensitivity. On the $\mathrm{X}$ axis, it will determine the good and bad values. The highest RMS score on the attributes analyzed indicates the attributes that play a role in program sustainability (Ngang \& Sam, 2015). In another dimension, the Y axis has a role to maintain the normality of ordination. Significant differences are shown by using Monte Carlo simulation.

The Monte Carlo analysis consisted of MDS (Rahardjanto \& Susilowati, 2018) that can be used to analyze the effect of errors from the process carried out. With a confidence level of $95 \%$ at the analysis stage, it will be known the differences between the results of MDS and the Monte Carlo. These results indicate that the program sustainability will run well with a confidence level of $95 \%$. Conversely, a large difference value indicates that sustainability is not going well. The value of stress determination and the value of the coefficient of determination (R2) is used to reflect the accuracy of the study dimension. This value shows the goodness of Fit function of the addition of attributes or in the MDS analysis. The value (R2) obtained is close to 1 indicating that the program sustainability status is good and the stress value is less than $0,25(S<0,25)$

\section{Result and Discussion}

Thru the LSLC program, the students will study together with the teachers who work professionally and develop the learning models (Hakim, 2017; Herliani \& Masitah, 2018; Rejeki et al., 2018; Saito \& Atencio, 2015; Setyawan et al., 2019; Yono et al., 2019). However, through the LSLC, the responsibility for students' education is not only delegated to the teachers in schools, but also involve the parents and other stakeholders in the development of education in schools (Rahardjanto et al., 2019). This shared responsibility in the field of education will encourage collaborative education in schools between the teachers and students, the teachers and other teachers, the teachers with stakeholders outside of school, as well as building up a good cooperation between one student and another in overcoming the learning problems. In brief, the Lesson Study processes of class in the school can be illustrated as the Figure 1. 


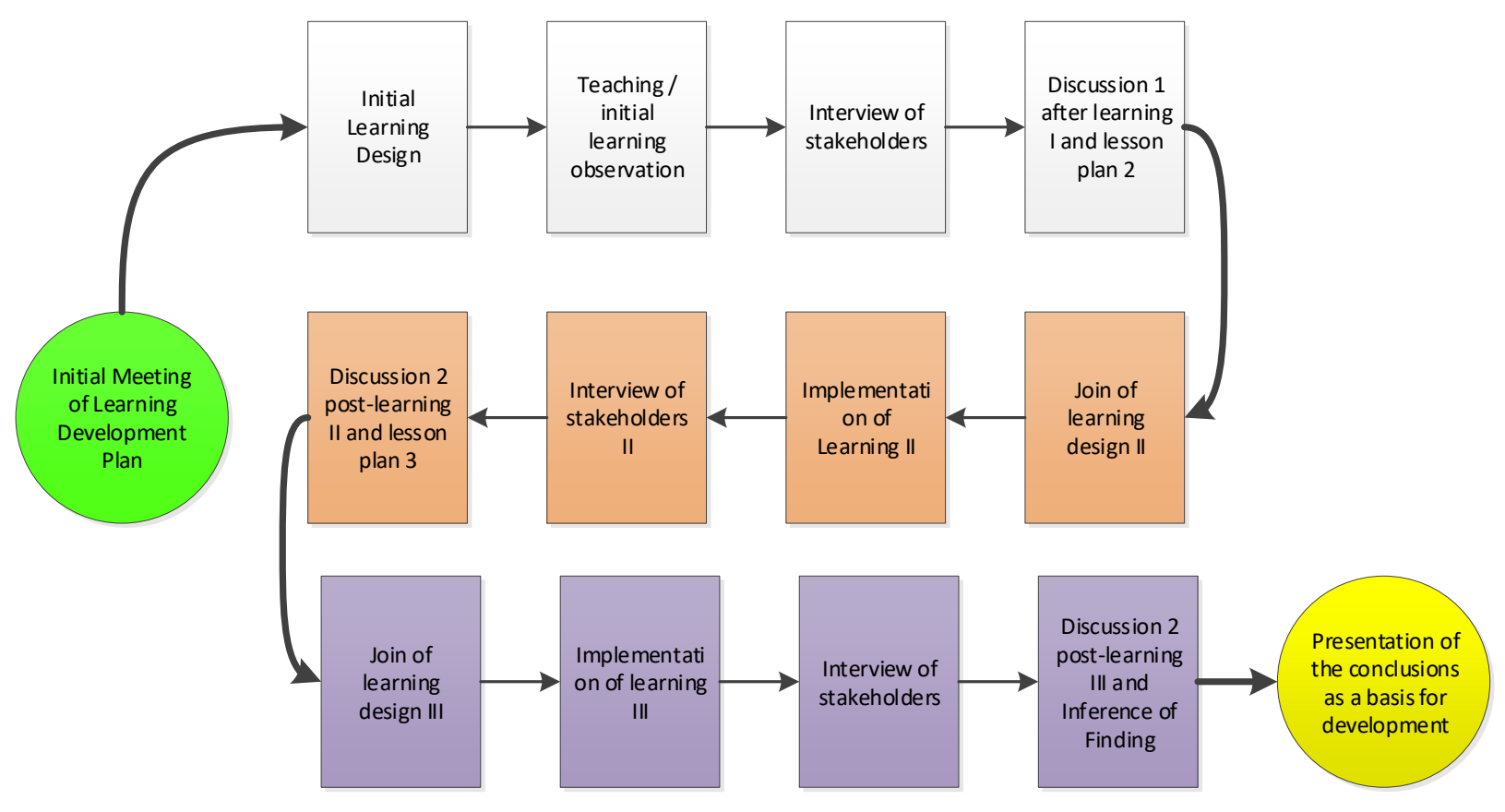

Figure 1. Lesson Study-based Learning Process

The description of the lesson study process above requires a professional action, as stated by Fernandez (2002), it is related to the learning process carried out in class. Curricular reform from a topdown model to a bottom-up model must be a fundamental paradigm shift for educators in schools. Education carried out in the school is expected to be an education which is closely related to the daily life of students (Tan et al., 2019); thus, the students can directly practice the learning outcomes in school on the development of life inquiry, culture, and critical thinking patterns in overcoming the problems.

The analysis of MDS in 5 dimensions that developed as a reference for the sustainability of LSLC program indicates that 3 dimensions are in a good category, while 2 dimensions show unfavorable results (Table 1). The highest value is in the pedagogic dimension; in which it is 77.2. Then, it is followed by the competence dimension with a value of 76.6, and the commitment dimension of 68.7. Furthermore, the subsidy dimension and socio-cultural show unfavorable numbers of 45.7 and 40.9. In the subsidy dimension and socio-cultural side, the program carried out has a smaller value when compared to the acquisition of other dimensions.

Table 1. The calculating results of Multidimensional Scaling on the 5 Dimensions of Lesson Study

\begin{tabular}{|c|c|c|c|c|c|c|}
\hline \multirow{2}{*}{ Dimension } & \multicolumn{2}{|c|}{ Sustainability Index } & \multirow[t]{2}{*}{ Difference } & \multicolumn{2}{|c|}{ Statistics } & \multirow[t]{2}{*}{ Iteration } \\
\hline & MDS & Monte Carlo & & Stress & R2 & \\
\hline Pedagogic & 77.2 & 77.3 & 0.01 & 0.15 & 0.96 & 2 \\
\hline Competence & 76.6 & 76.9 & 0.03 & 0.15 & 0.95 & 2 \\
\hline Socio-cultural & 40.9 & 40.9 & 0.04 & 0.14 & 0.95 & 2 \\
\hline Commitment & 68.7 & 68.9 & 0.02 & 0.14 & 0.95 & 2 \\
\hline Subsidy & 45.7 & 45.9 & 0.02 & 0.14 & 0.95 & 2 \\
\hline
\end{tabular}

Generally, by implementing the Lesson Study in school, the students' cognitive ability can be very well developed (84.6\%) based on the respondents' opinions. Meanwhile, the affective and psychomotor abilities are almost balanced, in which those are $42.3 \%$ and $49.3 \%$. In general, using lesson study can improve pedagogical skills (Veloo et al., 2013) in class by $77.2 \%$. The success of the program is as illustrated in the following kite diagram (Figure 2). 


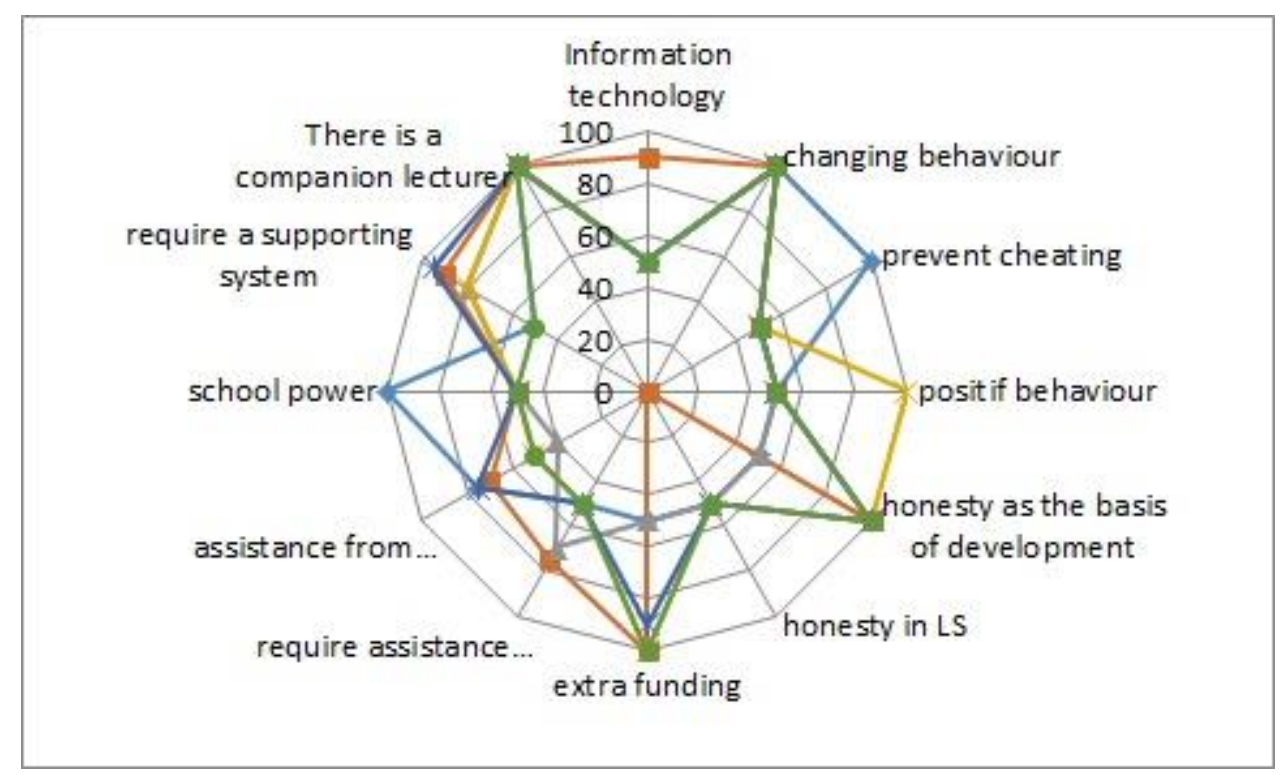

Figure 2. Kite diagram of LSLC program in Batu city

The activities carried out collaboratively between schools and various stakeholders had shown that they can strengthen the schools. This is reinforced by Galini et al (2014) who assert that the cooperation of stakeholders in the world of education is needed to develop the school. Yet, there are quite a lot of elements needed by the school to support the sustainability of LSLC activities in Batu City. The high extra costs, assistance from the educational support agencies, assistance from the local government (PEMDA) institutions, assistance from the energy sources of universities had put the value in the subsidy dimension of $45.7 \%$

\section{Ordination of Sustainability}

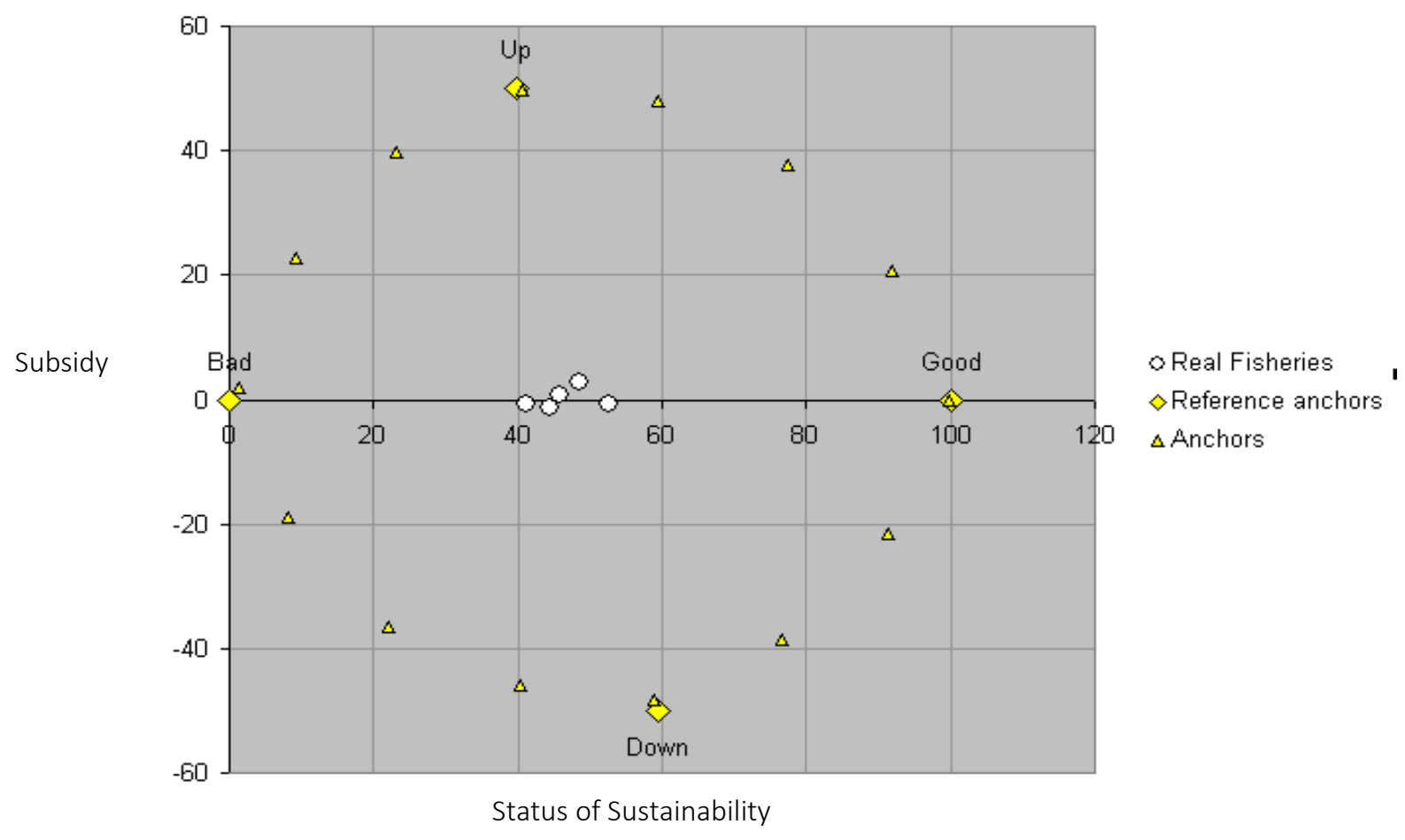

Figure 3. The ordination of sustainability of lesson study 
The subsidy position of $45,7 \%$ indicates that the LSLC activities in Batu City still need an external energy assistance to implement the LSLC program in schools. The subsidy is a part of activities that cannot be separated from all schools. Consequently, the implementation of the LSLC program for some time still requires support from a supporting system such as technology (hardware, software, and brain ware), funds, and networking. According to C. S. Lim et al (2018) attention to this is very necessary, because it is related to the issue of sustainability, and analyzed the possible challenges and constraints faced in an effort to sustain the lesson study practice. This is widely experienced in various countries. Studies for sustainability are also in line with the keyword in LS, namely "continuous improvement" (Babcock et al., 2011; Hunter \& Back, 2011). However, in LS the collaboration and networking aspects are the main things (Holmqvist, 2020; Lomibao, 2016; Stokes et al., 2020; Takahashi, 2014; Takahashi \& McDougal, 2016). Especially for networking, Nurwidodo et al (2018) recommends the following "In order for LSLC to manifest and become successful, resourcing and utilizing the partnership with schools are required. Networking with partner schools can be implemented and can function well when the management of this networking conforms to shared needs, nurtures cooperation and mutual respect, gives and takes equally, and also promotes fair acceptance, support, independence, and discipline". This recommendation is interesting to implement, as an effort towards the sustainability of LSLC, in Indonesia and specifically in Batu City.

Funding and technology adoption also plays an important role in the sustainability of learning. If this idea is taken into account, it will very likely provide an opportunity to solve problems and encourage creativity in organizers, an important point in determining education policy (Hird et al., 2014; Mardhia et al., 2013). On the other hand, LS which originated in Japan and has become popular all over the world (Grimsæth \& Hallås, 2015), which later developed into LSLC, has been adopted in different socio-cultures and educational contexts (Murata \& Lee, 2020). LSLC demands a reform of school culture, which is needed to change the level of learning among children, teachers, and even parents. LSLC is a comprehensive vision and framework for school reform and needs to be applied holistically across disciplines (Saito et al., 2015). Therefore, it is very important to strengthen the socio-cultural dimension in LSLC. LSLC aims to locate all the stakeholders and resources of the education system differently. People, resources, concepts and materials are seen as interrelated and inform one another to maximize learning in schools - for children, teachers and the local community. Schools seek to build society in meaningful and equitable ways - that is, they learn how to live, and learn, with other compassionate people (Saito \& Atencio, 2015).

\section{Conclusion}

The implementation of LSLC program in Batu City is a very effective activity in schools, in which it can develop three realms, namely cognitive, affective, and psychomotor of students. The activities carried out have positive impacts on the pedagogic, competence, Socio-cultural, and commitment dimensions. These four dimensions are a fundamental paradigm shift in the learning process carried out in schools. However, the sustainability of LSLC activities in Batu City has a weak point on the subsidy dimension. In this dimension, special attention is needed so that the LSLC program can continue to run, even though the subsidies from the government or parties outside the LSLC implementing agency are eliminated. Therefore, further studies can also be focused on this area so that an appropriate model or solution can be found to ensure the sustainability of the LSLC program.

\section{Acknowledgement}

Our gratitude goes to the Dean of the Faculty of Teacher Training and Education, Universitas Muhammadiyah Malang who has approved the implementation of this research and validated in FTTE Blockgrant 2019 (the Basic Scientific Research scheme).

\section{References}

Alamri, N. M. (2020). The Implementation of the Lesson Study Strategy in Teaching Mathematics: Teachers' Perspectives. Education Research International, 2020(1), 1683758. https: //doi.org/10.1155/2020/1683758

Angeles, D., \& Matsuura, T. (2020). Science Teachers' Successes and Challenges in Implementing Lesson Study in Junior High Schools in Fukuyama City, Japan. International Journal of Advances in Social and Economics, 2(3), 199. https://doi.org/10.33122/ijase.v2i3.199

Babcock, J. A., Stepanek, J., Appel, G., Leong, M., Mangan, M. T., Mitchell, M., \& Babcock, J. A. (2011). Review 
of Leading Lesson Study: A Practical Guide for Teachers and Facilitators A Review of Leading Lesson Study : A Practical Guide for Teachers Who the Book is For ... Networks : An Online Journal for Teacher Research, 13(1), 1-3.

Baymuradovna, B. S., Gaybullayevna, S. M., Sobirjonovna, D. D., \& Ramazonovna, Y. M. (2020). Pedagogical technologies for the development of cognitive creative abilities of students in the lessons of the Russian language. Journal of Critical Reviews, 7(6), 492-496. https://doi.org/10.31838/jcr.07.06.89

Bjuland, R., \& Mosvold, R. (2015). Lesson study in teacher education: Learning from a challenging case. Teaching and Teacher Education, 52, 83-90. https://doi.org/10.1016/j.tate.2015.09.005

Chenault, K. H. (2017). Building collaborative pedagogy: Lesson Study in higher education. College Quarterly, 20(1), 1-23.

Coenders, F., \& Verhoef, N. (2019). Lesson Study: professional development (PD) for beginning and experienced teachers. Professional Development in Education, 45(2), 217-230. https://doi.org/10.1080/19415257.2018.1430050

Cresswell, K., Coleman, J., Slee, A., Williams, R., \& Sheikh, A. (2013). Investigating and Learning Lessons from Early Experiences of Implementing ePrescribing Systems into NHS Hospitals: A Questionnaire Study. PLoS ONE, 8(1), e53369. https://doi.org/10.1371/journal.pone.0053369

Dudley, P. (2013). Teacher learning in Lesson Study: What interaction-level discourse analysis revealed about how teachers utilised imagination, tacit knowledge of teaching and fresh evidence of pupils learning, to develop practice knowledge and so enhance their pupils' lea. Teaching and Teacher Education, 34, 107-121. https://doi.org/10.1016/j.tate.2013.04.006

Fernandez, C. (2002). Learning from Japanese Approaches to Professional Development. Journal of Teacher Education, 53(5), 393-405. https://doi.org/10.1177/002248702237394

Galini, R., Constantine, K., \& Maria, M. (2014). Lesson Study application with students. Collaboration, reflection and feedback. Hellenic Journal of Research in Education, 1(2), 1-10. https://doi.org/10.12681/hjre.8935

Grimsæth, G., \& Hallås, B. O. (2015). Lesson study model: The challenge of transforming a global idea into local practice. Policy Futures in Education, 14(1), 109-122. https://doi.org/10.1177/1478210315612649

Gutierez, S. B. (2015). Collaborative professional learning through lesson study: Identifying the challenges of inquiry-based teaching. Issues in Educational Research, 25(2), 118-135. http://web.a.ebscohost.com.libproxy.unitec.ac.nz/ehost/pdfviewer/pdfviewer?sid=9107cc2404fd-4cec-b05e-c30b12c5489f@sessionmgr4002\&vid=9\&hid=4109

Haerullah, A., Mas'Ud, A., Nurhasanah, \& Sundari. (2019). Lesson learnt of the lesson study for learning community as the learning innovation in the 21st century for student. AIP Conference Proceedings, 2194(December). https://doi.org/10.1063/1.5139766

Hakim, L. (2017). Analisis perbedaan antara kurikulum KTSP dan kurikulum 2013. Jurnal Ilmiah Didaktika, 17(2), 280-292. https://doi.org/10.22373/jid.v17i2.1644

Herliani, H., \& Masitah, M. (2018). Implementation of Lesson Study Learning Community (LSLC) on Learning Science of Biology in State Junior High School. Advances in Intelligent Systems Research (AISR), 144, 78-82. https://doi.org/10.2991/icedutech-17.2018.14

Hindun, I., Nurwidodo, N., Wahyono, P., Miharja, F. J., \& Rais, A. (2019). Implementation of lesson study for learning community (LSLC): Impact on piloting school teachers in Batu City. 9th International Conference on Lesson Study, 204-211.

Hird, M., Larson, R., Okubo, Y., \& Uchino, K. (2014). Lesson Study and Lesson Sharing: An Appealing Marriage. Creative Education, 05(10), 769-779. https://doi.org/10.4236/ce.2014.510090

Holmqvist, M. (2020). Lesson study as a vehicle for improving SEND teachers' teaching skills. International Journal for Lesson and Learning Studies, 9(3), 193-202. https://doi.org/10.1108/IJLLS-05-20200022

Hunter, J., \& Back, J. (2011). Facilitating sustainable professional development through lesson study. 
Mathematics Teacher Education and Development, 13(1), 94-114. http://www.merga.net.au/publications/counter.php?pub=pub_mted\&id=131

Kaen, K., Study, L., \& Approach, O. (2011). Teachers 'Values about Teaching Mathematics in Classrooms , Implementing Lesson Study and.15(2), 115-126.

Kanellopoulou, E. M. D., \& Darra, M. (2019). Benefits, difficulties and conditions of lesson study implementation in basic teacher education: A review. International Journal of Higher Education, 8(4), 18-35. https://doi.org/10.5430/ijhe.v8n4p18

Lim-Ratnam, C. T.-L., Lee, C. K.-E., Jiang, H., \& Sudarshan, A. (2019). Lost in adaptation? Issues of adapting Japanese lesson study in non-Japanese contexts. Educational Research for Policy and Practice, 18(3), 263-278. https://doi.org/10.1007/s10671-019-09247-4

Lim, C. S., Teh, K. H., \& Chiew, C. M. (2018). Promoting and Implementing Lesson Study in Malaysia: Issue of Sustainability. In M. Quaresma, C. Winsløw, S. Clivaz, J. da Ponte, A. Ní Shúilleabháin, \& A. Takahashi (Eds.), Mathematics Lesson Study Around the World. ICME-13 Monographs (pp. 47-64). Springer, Cham. https://doi.org/10.1007/978-3-319-75696-7_3

Lim, E. W. K. (2015). A Review Lesson Study for Learning Community (LSLC). International Journal for Lesson and Learning Studies, 4(4), 418-420. https://doi.org/10.1108/IJLLS-02-2015-0009

Lofthouse, R., \& Cowie, K. (2018). Joining the dots: Using lesson study to develop metacognitive teaching. IMPACT, May.

Lomibao, L. S. (2016). Enhancing mathematics teachers' quality through Lesson Study. SpringerPlus, 5(1). https://doi.org/10.1186/s40064-016-3215-0

Mardhia, M. M., Bandung, Y., \& Langi, A. Z. R. (2013). Model development of mobile learning lesson study in teacher learning community. Proceedings of the 2013 Joint International Conference on Rural Information and Communication Technology and Electric-Vehicle Technology, RICT and ICEV-T 2013, 1-5. https://doi.org/10.1109/rICT-ICeVT.2013.6741563

Merdekawati, K. (2020). Lesson study for learning community through collegial collaboration. AIP Conference Proceedings, 2229(1), 20011. https://doi.org/10.1063/5.0002783

Merga, M. K. (2019). Collaborating With Teacher Librarians to Support Adolescents' Literacy and Literature Learning. Journal of Adolescent and Adult Literacy, 63(1), 65-72. https://doi.org/10.1002/jaal.958

Miharja, F. J., Hindun, I., Wahyono, P., Nurwidodo, N., \& Susetyarini, E. (2017). Lesson study based learning practical development for prospective teacher in higher education. Proceeding Abstract of WALS International Conference 2017, PP-155. http://www.wals2017.com/program/program/pdf/ppd13.pdf

Murata, A., \& Lee, C. K. E. (2020). Stepping Up Lesson Study: An Educator's Guide to Deeper Learning. Routledge.

Ngang, T. K., \& Sam, L. C. (2015). Principal support in lesson study. Procedia - Social and Behavioral Sciences, 205, 134-139. https://doi.org/10.1016/j.sbspro.2015.09.040

Norwich, B., \& Jones, J. (Eds.). (2012). Lesson study: making a difference to teaching pupils with learning difficulties. Bloomsbury. https://doi.org/10.1080/17508487.2014.938242

Nurwidodo, N. (2016a). Lesson learned lesson study for learning community at Batu City East Java. WALS International Conference 2016.

Nurwidodo, N. (2016b, September 20). Mendorong lesson study menuju learning community (LSLC). Malang Post, Opini.

Nurwidodo, N., Hendayana, S., Hindun, I., \& Sarimanah, E. (2018). Strategies for establishing networking with partner schools for implementing lesson study in Indonesia. JPBI (Jurnal Pendidikan Biologi Indonesia), 4(1), 11-22. https://doi.org/10.22219/jpbi.v4i1.5489 11

Purwandi, D., Susanto, S., \& Hobri, H. (2020). Development of remedial mathematics learning based on lesson study for learning community against students' problem solving analysis capabilities. Journal of Physics: Conference Series, 1563(1). https://doi.org/10.1088/17426596/1563/1/012038 
Purwanti, E., \& Hatmanto, E. (2019). Introducing Lesson Study to Improve Student Learning in the Classroom. Advances in Social Science, Education and Humanities Research, 353(IcoSIHESS), 3642. https://doi.org/10.2991/icosihess-19.2019.6

Rahardjanto, A. (2015). Simple Method to Evaluate of River Quality based on Riparian Vegetation Bioindicator. 25-35.

Rahardjanto, A., Husamah, H., \& Fauzi, A. (2019). Hybrid-PjBL: Learning outcomes, creative thinking skills, and learning motivation of preservice teacher. International Journal of Instruction, 12(2), 179192. https://doi.org/10.29333/iji.2019.12212a

Rahardjanto, A., \& Susilowati, R. (2018). Study of Learning Strategy Integration of Science and Religion on the Development of Student Character. 231(Amca), 645-648. https://doi.org/10.2991/amca18.2018.178

Rappleye, J., \& Komatsu, H. (2017). How to make Lesson Study work in America and worldwide: A Japanese perspective on the onto-cultural basis of (teacher) education. Research in Comparative and International Education, 12(4), 398-430. https://doi.org/10.1177/1745499917740656

Rejeki, S., Humaira, H., Maryani, S., \& Nizar. (2018). Lesson Study For Learning Community (LSLC): Pengalaman Berharga Dalam Pengelolaan Pembelajaran Secara Terbuka. INOPENDAS: Jurnal Ilmiah Kependidikan, 1(1), 54-60. https://jurnal.umk.ac.id/index.php/pendas/article/view/2318/1346

Rozimela, Y. (2018). Developing Teachers' Professionalism through School Initiative-Based Lesson Study. European Journal of Educational Research, 9(4), 1513-1526. https://doi.org/10. 12973/eu-jer. 9. 4. 1513

Saito, E., \& Atencio, M. (2015). Lesson study for learning community (LSLC): Conceptualising teachers' practices within a social justice perspective. Discourse: Studies in the Cultural Politics of Education, 36(6), 795-807. https://doi.org/10.1080/01596306.2014.968095

Saito, E., Murase, M., Tsukui, A., \& Yeo, J. (2015). Lesson Study for Learning Community: a guide to sustainable school reform. Routledge.

Saito, E., \& Sato, M. (2012). Lesson study as an instrument for school reform: A case of Japanese practices. Management in Education, 26(4), 181-186. https://doi.org/10.1177/0892020612445101

Sato, M. (2018). Spread and progress of School as Learning Community in Asia. In Lesson Study and Schools as Learning Communities Asian School Reform in Theory and Practice (pp. 3-13). Taylor \& Francis. https://doi.org/10.4324/9781315690322-1

Setyawan, D., Permana, T. I., \& Latifa, R. (2019). Lesson study for learning community: A way of collegial participation of teachers and lecturers. Jurnal Bioedukatika, 7(1), 1-10. https://doi.org/10.26555/bioedukatika.v7i1.11936

Stokes, L. R. E., Suh, J. M., \& Curby, T. W. (2020). Examining the nature of teacher support during different iterations and modalities of lesson study implementation. Professional Development in Education, 46(1), 97-111. https://doi.org/10.1080/19415257.2019.1634623

Suratno, S., Komaria, N., Hobri, H., Husniah, F., Novenda, I. L., \& Fahroyin, M. (2020). Biotechnology concept: Questioning of analysis with lesson study for learning community (LSLC) for higher ordered thinking skill on coffee area plantation. Journal of Physics: Conference Series, 1563(1). https://doi.org/10.1088/1742-6596/1563/1/012040

Suratno, T., Joharmawan, R., Chotimah, H., \& Takasawa, N. (2019). Harbinger of Lesson Study for Learning Community in Indonesia. In Lesson Study and Schools as Learning Communities Asian School Reform in Theory and Practice (pp. 74-89). Taylor \& Francis. https://doi.org/10.4324/9781315690322-6

Takahashi, A. (2014). Supporting the Effective Implementation of a New Mathematics Curriculum: A Case Study of School-Based Lesson Study at a Japanese Public Elementary School. Mathematics Curriculum in School Education, 417-441. https://doi.org/10.1007/978-94-007-7560-2_20

Takahashi, A., \& McDougal, T. (2016). Collaborative lesson research: Maximizing the impact of lesson study. ZDM - Mathematics Education, 48(4), 513-526. https://doi.org/10.1007/s11858-0150752-x 
Tan, Y. S. M., Amiel, J. J., \& Yaro, K. (2019). Developing theoretical coherence in teaching and learning: case of neuroscience-framed learning study. International Journal for Lesson and Learning Studies, 8(3), 229-243. https://doi.org/10.1108/IJLLS-10-2018-0072

Tsukui, A., \& Murase, M. (2018). Lesson Study and Schools as Learning Communities Asian School Reform in Theory and Practice. Routledge. https://doi.org/10.4324/9781315690322

Uştuk, Ö., \& Çomoğlu, İ. (2019). Lesson study for professional development of english language teachers: Key takeaways from international practices. Journal on Efficiency and Responsibility in Education and Science, 12(2), 41-50. https://doi.org/10.7160/eriesj.2019.120202

Veloo, A., Komuji, M. M. A., \& Khalid, R. (2013). The Effects of Clinical Supervision on the Teaching Performance of Secondary School Teachers. Procedia - Social and Behavioral Sciences. https://doi.org/10.1016/j.sbspro.2013.09.148

Widoretno, S., \& Dwiastuti, S. (2019). Improving students' thinking skill based on class interaction in discovery instructional: A case of lesson study. Jurnal Pendidikan IPA Indonesia, 8(3), 347-353. https://doi.org/10.15294/jpii.v8i3.20003

Wood, K. (2018). On the theorization of lesson study and learning study. International Journal for Lesson and Learning Studies, 7(3), 166-171. https://doi.org/10.1108/IJLLS-05-2018-0033

Yono, S., Zulkardi, \& Nurjannah. (2019). 8th Grade Student's Collaboration in Circle Material by Using System Lesson Study for Learning Community. Journal of Physics: Conference Series, 1315(1), 012012. https://doi.org/10.1088/1742-6596/1315/1/012012

Yuniar, D., Hobri, Prihandoko, A. C., Aini, K., \& Faozi, A. K. A. (2020). The analyze of students' creative thinking skills on Lesson Study for Learning Community (LSLC) based on Science, Technology, Engineering, and Mathematics (STEM) approach. Journal of Physics: Conference Series, 1538(1), 012072. https://doi.org/10.1088/1742-6596/1538/1/012072 